\title{
SOME EXPERIENCES WITH THE BREEDING OF POINTED-HEADED CABBAGE
}

\author{
M. NIEUWHOF \\ Institute of Horticultural Plant Breeding, Wageningen, Holland \\ With 3 figures \\ Received 8 Aug. 1959
}

\begin{abstract}
1. A survey is given of research on pointed-headed cabbage carried out at the I.V.T. from 1947 to 1957 . The aim has been to ascertain whether the production of hybrid seed will make it possible to increase the uniformity and cultural value. Three strains of pointed-headed cabbage were used.

2. It was found that the $F_{1}$ 's from pair crosses between plants of the same strain were usually very uniform. By comparison it was possible to find out which parents gave on an average the earliest progenies. Crossing these early parents sometimes resulted in increased earliness.

3. By maintaining the two best parents vegetatively it is easy to maintain a certain selection level.

4. No decline in quality and yield occurred when an $F_{1}$ from a pair cross of two closely related parents was propagated for two generations without previous selection.

5. Indications were obtained that some hybrid vigour occurs in the $F_{1}$-generation.
\end{abstract}

\section{INTRODUCTION}

In the Netherlands from 100 to 150 ha is annually cropped to pointed-headed cabbage. Sowing is done under glass in September; the young plants are pricked off into pots in the autumn, and planted outside early in spring.

Harvest begins in May, and the bulk of the crop is marketed in June, so it is the earliest white cabbage. In the Netherlands only strains of the variety Eersteling are now used for early production of pointed-headed cabbage; a few years ago also strains of the variety Sappemeerse were used. The productivity of these varieties is lower than that of the round-headed white varieties and amounts to about $20,000 \mathrm{~kg}$ per ha. As the round-headed varieties are later, however, early pointed-headed cabbage is still being grown, though on a limited scale.

From preliminary variety trials carried out in 1946-1947 it appeared that some strains of the above varieties were far below average in regard to earliness and uniformity. Therefore a start was made with the testing of some selection methods. The present article gives a survey of this work.

The investigations were initiated by Dr. J. SNEEP, taken over by Dr. J. R. JENSMA in 1953 , and finished by the present author in the years 1955-1957.

\section{MATERIAL AND METHODS}

Three strains were used, two of which belonged to the variety Eersteling (fig. 2). 
One of them, called Vroegste van Allen (Earliest of All), was medium early. Its productivity was too low in relation to its time of ripening. Its uniformity was only moderate. The uniformity of the other strain, called Eerste van de Markt (First of the Market), was slightly better. This strain also had a small head, but it was earlier. The third strain belonged to the variety Sappemeerse (fig. 3) and was somewhat later than Eerste van de Markt. It was fairly uniform. According to the breeder this strain is a hybrid derived from two parent plants that were maintained and propagated asexually.

The crosses made in 1948 were done by hand. As in this manner the amount of seed obtained from each cross is often insufficient, use was made in subsequent years of pollination cages to which small bee colonies or diseased bumble-bee queens were added to do the pollination (fig. 1). In this manner seed setting was usually good. A paper on this pollination method has already appeared (1).

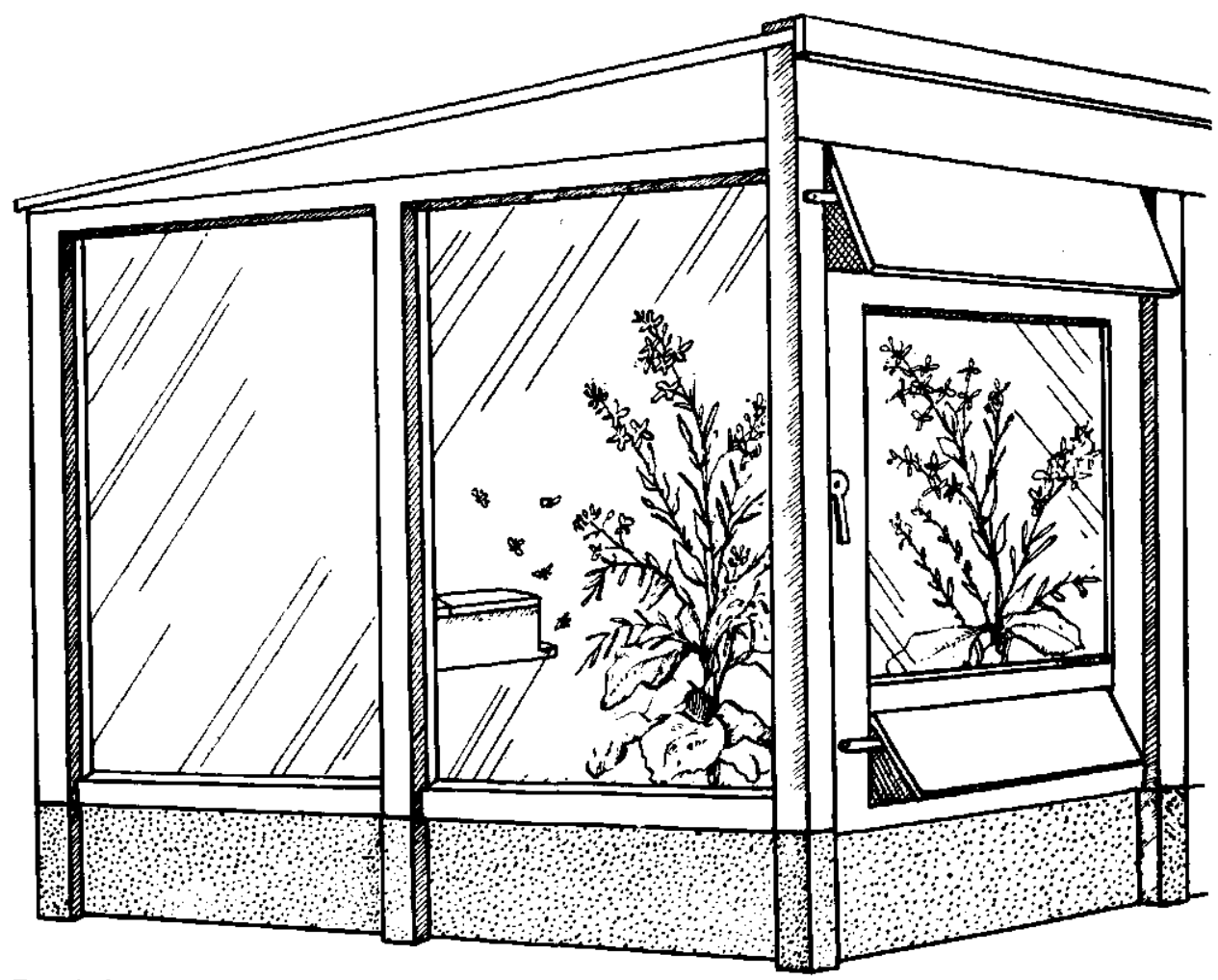

Fig. 1. Pollination cage

In some cases plants were also open-pollinated in the field, taking care to leave at least $500 \mathrm{~m}$ between them and other flowering cabbage plants; in many instances it was more than $1,000 \mathrm{~m}$.

The resulting populations were tested on river clay at Elst in a normal spring production. The majority of the trials were not replicated, so that in many cases it was not possible to test differences found statistically. They were mostly judged by eye. 


\section{BREEDING OF POINTED-HEADED CABBAGE}

Special attention was paid to uniformity and earliness. Uniformity is a measure of the suitability of a certain method, while earliness is of much importance to the grower. Moreover attention was sometimes given to productivity and rate of cracking. Notably the early strains are very subject to cracking. Hence they must be harvested as soon as possible, which may be a drawback if prices are low.

\section{Selection in Vroegste Van AlLen}

\section{Pair crosses}

In 1947, 20 early plants of about the same type were selected. They were indicated by the letters A-U (the letter I is not used). With these, 43 crosses were made in 1948, which were compared in 1949.

As in 1948 the crosses were made by hand, the amount of available seed of various strains was only small and consequently the assessments in 1949 were not very reliable. The impression was obtained that the parent plants $\mathrm{B}$ and $\mathrm{E}$ produced on an average the earliest $F_{1}$ 's. The uniformity of the $F_{1}$ 's was generally good. A number of crosses, including the cross $\mathrm{B} \times \mathrm{E}$, were repeated in 1949. This was possible because the parent plants had been maintained vegetatively by means of shoot cuttings. By judging the progenies of the selected plants it is possible to find out which parent plants are genetically the best. This is a form of parent selection. By maintaining the two best parent plants vegetatively, in the present case $B$ and $E$, crosses between them can always be made. In this manner a hybrid variety is obtained.

\section{Propagation of the $F_{1}$ 's}

This method has the disadvantage that a great many cuttings of plants B and E have to be maintained for commercial seed production. Therefore it was investigated whether the $F_{1}$ seed could be propagated without loosing its qualities. To this end a number of $F_{1}$ 's were sown in July 1949 for seed production. In 1950 the resulting plants flowered without forming a head. Each cross flowered separately. With some of these $F_{1}$ 's double crosses were also made and part of the seed derived from these crosses was sown in July 1950. In 1951 their progenies flowered separately. So in this propagation no selection work was done.

A comparison, in 1951 and 1952 , of the $F_{1}$ 's, $F_{2}$ 's and $F_{3}$ 's did not show great differences. Most strains were much uniformer and also a little earlier than the original strain. Consequently an $F_{1}$ of a single cross between two closely related parents may in some cases be propagated for one or two generations without selection.

In 1952 the strains were rated on earliness and classed as "fairly early" and "medium early". Of the 9 strains that were "fairly early" 6 had both B and E as the original parent plant. Of the 18 "medium early" strains none had B or E as a parent. So the increased earliness of these parents was also retained when the crosses were propagated. The double crosses largely resembled the $F_{1}$ 's that had been propagated separately.

\section{Selection in Eerste van de Markt}

\section{Pair crosses}

A number of plants were selected in 1948 and paired in 1949. They were judged in 1950 and it was found that there were hardly any differences between the $F_{1}$ 's, in con- 


\section{NIEUWHOF}

trast with the $F_{1}$ 's of Vroegste van Allen. The cause probably had to be sought in the fact that most plants of Eerste van de Markt were early. From this strain early plants were selected, i.e. those of the current type. The chance of these being genetically closely related was much larger than for the plants of Vroegste van Allen. This strain was less uniform and later, and the plants selected from it deviated from the normal type in that they were earlier.

The uniformity of the $F_{1}$ 's was generally good. This is also evidenced by the fact that in 1950 there were only $2-3$ days between the date on which $25 \%$ of the heads were ripe for harvesting and the date on which this percentage was $75 \%$.

The propagation of the $F_{1}$ 's

In 1950 and 1951 the $F_{1}$ 's were propagated twice, without selection. The $F_{1}$ 's and their progenies always flowered separately. In 1951 and 1953 the $F_{1}$ 's and $F_{2}$ 's were also propagated after previous selection in 1950 and 1952, respectively. In 1951 the $F_{1}$ 's were compared with the $F_{2}$ 's propagated without selection. The average results of three plots of 4 crosses each are shown in table 1 .

TABLE 1. Yield, EARLINESS AND RATE OF CRACKING IN $F_{1}$ AND $F_{2}$ OF EERSTE VAN DE MARKT

\begin{tabular}{c|cc|cc|cc}
\hline Cross & $\begin{array}{c}\text { Net weight per head } \\
\text { in } \mathrm{kg}\end{array}$ & $\begin{array}{c}50 \% \text { harvesting date } \\
\text { (days in June) }\end{array}$ & $\begin{array}{c}\text { Number of days from } 50 \% \text { harvesting } \\
\text { date to date on which } 50 \% \text { of } \\
\text { the heads were cracked }\end{array}$ \\
\hline & $\mathrm{F}_{1}$ & $\mathrm{~F}_{2}$ & $\mathrm{~F}_{1}$ & $\mathrm{~F}_{2}$ & $\mathrm{~F}_{1}$ & $\mathrm{~F}_{2}$ \\
1 & 1.11 & 1.07 & 11.3 & 13.8 & 3.4 & 4.0 \\
2 & 0.97 & 0.96 & 12.6 & 12.5 & 3.0 & 3.0 \\
3 & 1.14 & 0.99 & 11.5 & 12.3 & 3.0 & 3.7 \\
4 & 1.06 & 0.93 & 12.0 & 14.0 & 4.0 & 6.5
\end{tabular}

In three of the four crosses the $F_{2}$ 's yielded a little less than the $F_{1}$ 's, while they were also somewhat later and cracked less rapidly. The differences, however, were small.

From the trials made in 1951 and subsequent years significant differences between propagation with and without previous selection were not shown.

In 1953 seed of some $F_{1}$ 's from Eerste van de Markt was distributed to private seed firms.

\section{SELECTION IN SAPPEMEERSE}

$F_{1}$ 's were propagated twice, viz. in 1951 and 1953, after previous selection. In both years the seed of the plants was harvested collectively (positive mass-selection). In the trials made in 1952 and subsequent years differences between the various generations were generally not large. That they could not be neglected, however, appeared in 1955 when somewhat more extensive observations were made. These data are given in table 2.

It will be seen that the $F_{2}$ and $F_{3}$ are more uniform and earlier than the $F_{1}$, among which in some cases an appreciable amount of contamination (propably with kale) as well as a number of round-headed plants occurred. 
BREEDING OF POINTED-HEADED CABBAGE

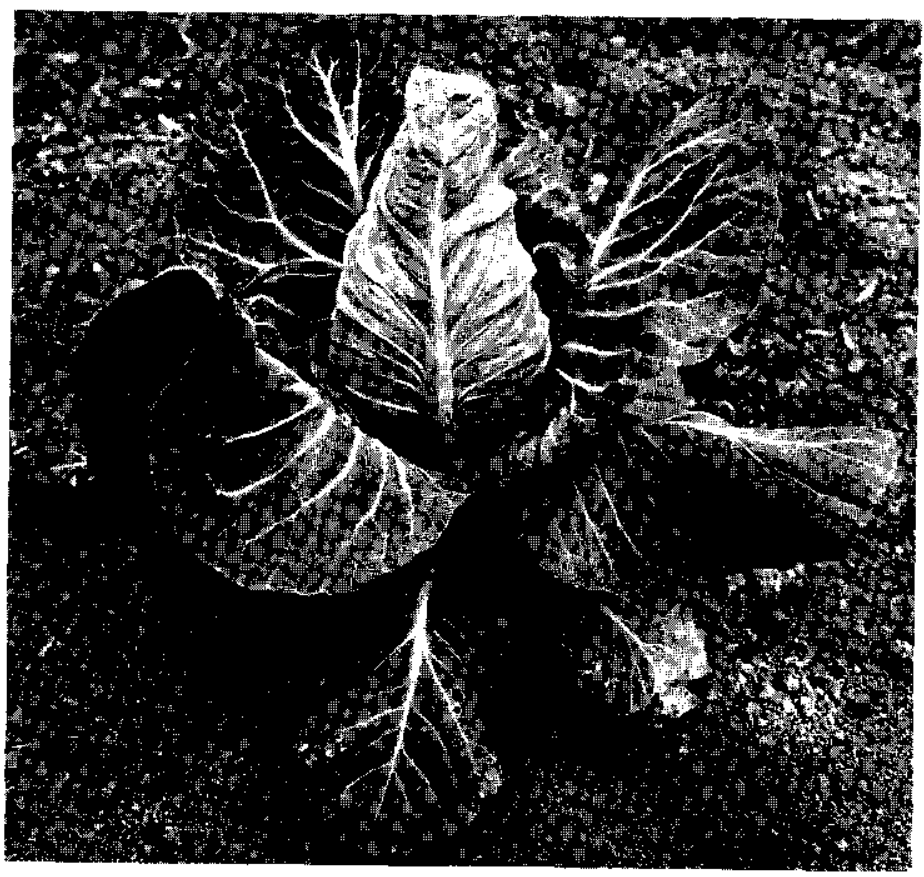

Fig. 2. A blant of thi: varifty Eerstiling

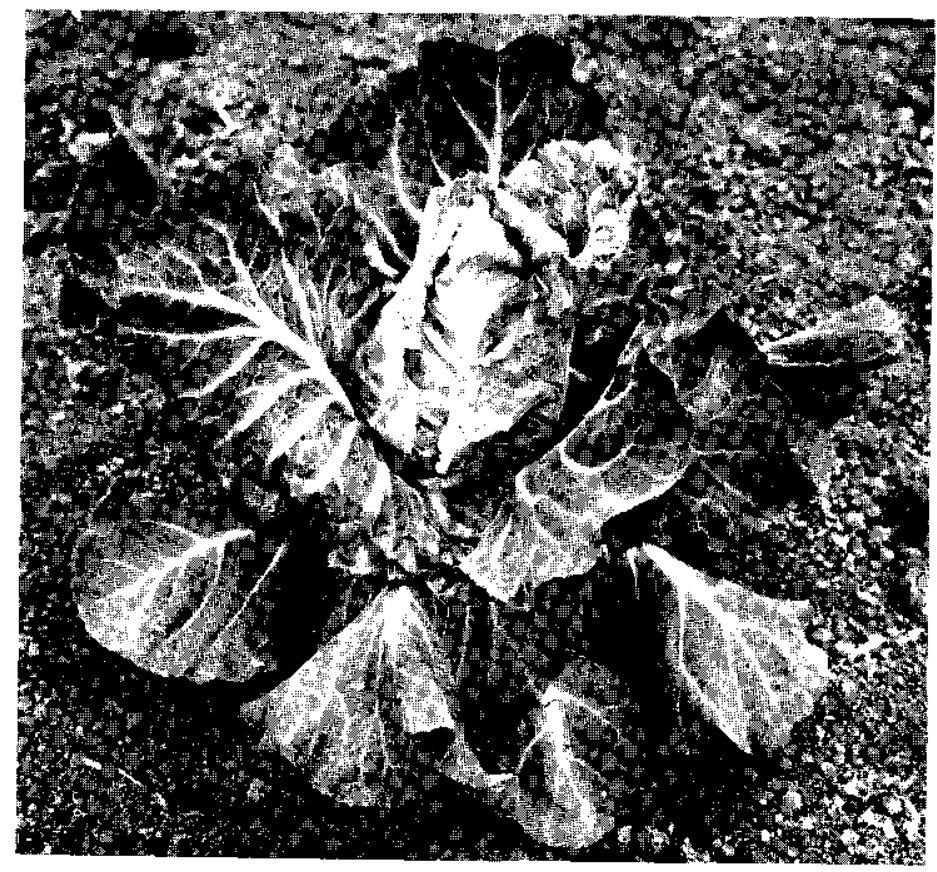

Fig. 3. A PLANT OF THE VARIITY SAPPEMIIIRSE 
BREEDING OF POINTED-HEADED CABBAGE

TABLE 2. UNIFORMITY AND EARLINESS OF SAPPEMEERSE

\begin{tabular}{c|l|c|c}
\hline \multirow{2}{*}{ Generation } & Uniformity & \multicolumn{2}{|c}{ Percentage harvestingripe on } \\
\cline { 3 - 4 } & & $16 / 6$ & $20 / 6$ \\
\hline \multirow{3}{*}{$F_{1}$} & moderate & 10 & 40 \\
$F_{2}$ & rather good & 30 & 65 \\
$F_{3}$ & rather good & 40 & 90
\end{tabular}

\section{Discussion}

The variability inherent in naturally cross-pollinated plants can be considerably reduced by the production of hybrid varieties. These are obtained by breeding inbred lines, subjecting them to test crosses, and using the two best for the production of hybrid seed. The two inbred lines are always propagated sexually. Various Japanese cabbage varieties are obtained in this manner.

Using the method discussed in this paper, test crosses between the selected plants are made immediately. Since the selected plants can be maintained vegetatively, the best $F_{1}$ 's can always be reproduced again. Thus it is possible to maintain a certain selection level.

The present experiments have clearly shown that crosses between phenotypically identical cabbages, selected from a population, may yield a sufficiently uniform $F_{1}$ of high cultural value. It is not likely, however, that in this manner much heterosis will occur, as the parents are genetically too closely related. Yet the data in table 1 seem to indicate that the $F_{2}$ is somewhat less vigorous than the $F_{1}$. This might point to some hybrid vigour in the $F_{1}$. The differences, however, are small. Attempts might be made to increase hybrid vigour by using parents that are genetically more different. An $F_{1}$ thus obtained will presumably be less uniform and more difficult to propagate sexually while retaining its favourable characters. This is a drawback, as the production of $F_{1}$ seed from parents maintained and propagated vegetatively can only be carried out on a limited scale. Therefore in large-scale seed production the $F_{1}$ seed should also be suitable for sexual propagation. In the above crosses the $F_{1}$ 's could be propagated without materially affecting their quality.

Summarizing we may say that the production of $F_{1}$ varieties by pairing the selected plants immediately, without previously selfing them for a number of generations, will lead to rapid results. However, the necessity of maintaining the parent plants vegetatively is a disadvantage and a weak point. Owing to diseases or insufficient care the parents may become lost. Moreover, it will be more difficult to obtain so much $F_{1}$ seed as with the previously mentioned method, as the large-scale vegetative propagation of the parent plants requires more labour than the generative maintenance of the inbred lines. It is therefore of importance that the $F_{1}$ 's can be propagated once or twice sexually without loosing too much of their quality. This is only possible if both parents have almost the same genetical constitution, as otherwise there will be too much segregation in the $F_{2}$ and $F_{3}$. Consequently it will be difficult to breed a heterosis variety in this way.

The procedure discussed in this paper may also prove useful for the selection of inbred lines. The combining ability of the parent plants might give an indication of the combining ability of the inbred lines which may be derived from them by selfing. 


\section{SAMENVATting}

Enige ervaringen met het kweken van spitskool

1. Een overzicht wordt gegeven van het onderzoek met spitskool dat in de jaren 1947 tot 1957 bij het I.V.T. plaats vond. De opzet was na te gaan of de produktie van hybridezaad mogelijkheden biedt de uniformiteit en de gebruikswaarde op te voeren. Er is gewerkt in een drietal spitskoolselecties.

2. Het bleek dat de $F_{1}$ 's van paarsgewijze kruisingen tussen planten uit dezelfde selectie doorgaans zeer uniform waren. Door deze met elkaar te vergelijken, bleek het mogelijk na te gaan welke kruisingsouders gemiddeld de vroegste nakomelingen gaven. Door deze vroege kruisingsouders daarna weer met elkaar te kruisen, kon soms enige vervroeging worden verkregen.

3. Door vegetatieve instandhouding van de 2 beste kruisingsouders kan een eenmaal bereikt selectie-niveau gemakkelijk gehandhaafd worden.

4. Vermeerdering van een door paarsgewijze kruising verkregen $F_{I}$ van nauw verwante ouders gedurende twee generaties in stullenteelt bleek geen beduidende achteruitgang in kwaliteit en opbrengst te veroorzaken.

5. Aanwijzingen werden verkregen dat in de $F_{1}$ enige heterosis optreedt.

\section{REFERENCE}

1. KraAi, A., The use of honey-bees and bumble-bees in breeding work. Euphytica 3 (1954): 97-107. 


\section{PUBlications OF THE INSTITUTE OF HORTICULTURAL PLANT BREEDING}

The following publications can be obtained in one of three ways:

a. by ordering them from the Institute of Horticultural Plant Breeding (I.V.T.), P.O. Box 16, WazeningenNetherlands

b. by sending in exchange publications that are of interest to the I.V.T.

c. by borrowing them from the I.V.T. library

\section{Rassenlijsten/Variety lists}

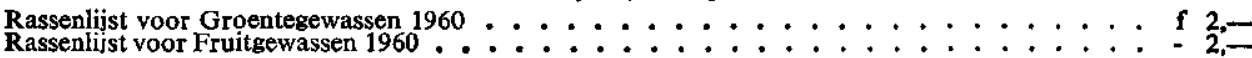

Rasbeschrijvingen/Varietal Descriptions

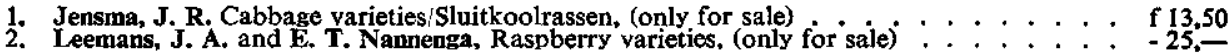

\section{Mededelingen/Communications}

106. Andeweg, J. M. and J. H. Ruyten. Seven years experience with hybrid tomatoes. Juni 1957

107. Floor, J. Report on the selection of a dwarfing rootstock for cherries. Juni 1957 . . . .

108. Banga, O. Horticultural plant breeding in the Netherlands, Juni 1957 . C. van der and A. van Steenbergen. A new method of testing beans for Anthrac: Giessen, A. C. van der and A. van Steenbergen. A new method of testing beans for Anthrac

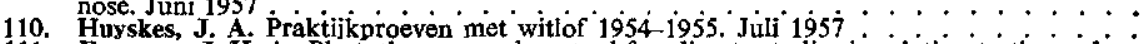

111. Ferguson, J. H. A. Photothermographs a tool for climate studies in relation to the ecology of vegetable varieties. Oktober 1957 .

112. Sneep, J. Geschiedenis van de spinazie en het ontstaan van de rassen. Oktober $1957^{\circ} \cdot{ }^{\circ}$

113. Sneep, J. De stand van de veredeling bij spinazie. Dissertatie, Wageningen, november 1957 1957

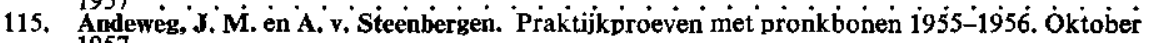

116. Garretsen, $\dot{\mathbf{F}}$, en H. G. Kronenberg. Opbrengstproeven met zwarte bessen. oktober 1957 .

117. Bruyn, J. W. de. Het gehalte aan mydriatische alkaloiden van Scopolia lurida. Oktober 1957

119. Braak, J. P. and A. E. Zeilinga. Production of a colchicine-induced tetraploid asparagus. December 1957 .

120. Andeweg. J. M. and $\dot{A}$. van Kooten. The practical importance of an identification of garden pea varieties in the seedling stage. December 1957 . ${ }^{2}$. Januari 1959 .

122. Banga, $O$. Effect of some environmental factors on the carotene content of carrots. Januari 1958

123. Elzenga, $\dot{G}$. Influence of external factors on the alkaloid content in some medicinal plants. Gerritsen. C. j. Zijn er in Nederland mogelijkheden voor de teelt van buitenperziken. Fe

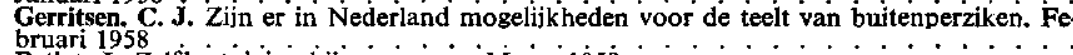
Petiet, J. Zelf bestuiving bij anemonen. Maärt 1958

Nieuwhof, M. en A. Kraai. Praktijkproeven met spitskool 1956-1957. April 1958: : : Gerritsen, C. J. De tamme kastanje een fruitgewas? April 1958 . 1958

129. Huyskes, J. Het kweken van zwaardere glasslarassen. Juli $1958^{\circ} \cdot \cdots$

130. Kraai, A. Bijen en hommels bij het veredelingswerk Juli 1958 131. Banga, $O$. and J. Petiet. Breeding male sterile lines of Dutch onion varieties as a preliminary to the breeding of hybrid varieties. Juli 1958 Nieuwhof, M. Vegetative maintenance and propagation of cauliflower. September $1958^{\circ}$

134. Ferguson, J. H. A. Empirical estimation of thermoreaction curves for the rate of development. September 1958

135. Braak, J. P and Y. O. Kho. Some observations on the floral biology of the carrot (Daucus

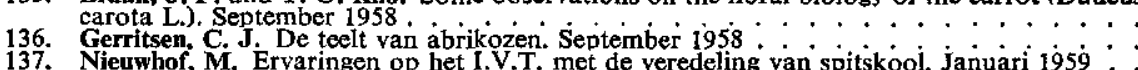

137. Nieuwhof, M. Ervaringen op het I.V.T. met de veredeling van spitskool. Januari $195 \dot{9}^{\circ}$ :

138. Nieuwhof, M. en A. Kraai. Praktijkproeven met het bloemkoolras Lecerf 1956-1957 . : :

139. Gerritsen, C. J. De Amandel. Februari 1959

140. Huyskes, J. A. Praktijkproeven met herfst-en winterprei $1955^{\circ}$ en 1956. Februari 1959"

141. Banga, O., J. W. de Bruyn, J. L. van Bennekom en H. A. van Keulen. Selection of carrots for carotene content. IV Reduction of the gas exchange of the soil. Maart 1959 . . . . . .

142. Wiering, D. Artificial pollination of cabbage plants. Maart 1959 . The

143. Rodenburg, C.M. The identification of lettuce yarieties from the young plants. Maart 1959

Gerritsen, C. J. De vijg. Maart 1959

146. Jensma, J. R. Rassenproeven met savooickool Maart $1959^{\circ}$. . . . . . . . . . . . . .

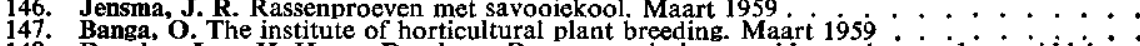

148. Douglas, $J$. en $\mathbf{H}$. H. van Doesburg. De vermeerdering van blauwe bessen door middel van scheutstekken. April 1959

149. Gerritsen, $\mathbf{C}$. J. Een hoger rendement bij de teelt van hazelnoten. Mei $1959^{\circ} \dot{*}^{*}::^{*}$

150. Andeweg, J. M., and J. W. de Bruyn. Breeding of non-bitter cucumbers. Juli 1959

151. Huyskes, J. A. A method for selecting asparagus varieties with a long fibreless top. Juli 1959

152. Bruyn, J. W. de, en J. G. van Hall. De bepaling van kleine hoeveelheden hyoscyamine en scopolamine in geneeskruiden. Augustus 1959

153. Nieuwhof, M. Some experiences with the breeding of pointed headed cabbage. November 1959

154. Nieuwhof, $\dot{M}$. Problems in the design of variety trials with spring cabbage. November 1959

155. Szteyn, K. Trials to overcome the incompatibility of crosses between Lycopersicum esculen-

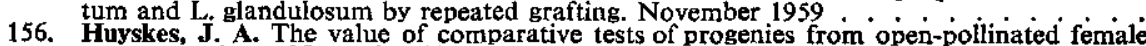
asparagus plants. November 1959 . 


\title{
INSTITUUT VOOR DE VEREDELING VAN TUINBOUWGEWASSEN
}

\author{
Institute of Horticultural Plant Breeding \\ DIRECTOR: DR. O. BANGA \\ ASSISTANT DIRECTOR: IR. J. GROENENDIJK
}

15 Dr. S. L. Mansholtlaan, Wageningen, The Netherlands. Telephone 3141

The general purpose of the Institute is the improvement of horticultural plants, inclusive of tobacco, and the investigation of problems in this field and in related ones.

It works under a board of plant breeders and growers, and is supervised by the Ministry of Agriculture.

The activities of the Institute comprise:

1. Research on varieties of horticultural plants:

a. General documentation

b. Plant introduction

c. Distinctive characters

d. Cultural value

2. Research on methods of horticultural plant breeding and, as far as necessary, breeding work itself.

3. Research on seed growing and vegetative propagation.

4. Advisory work in these fields.

\section{Members of Staff:}

Breeding methods and special crops (including bulb and root crops): Dr. O. Banga;

Ornamentals: Ir. J. Groenendijk (temporary).

'Boskoop'crops: Ir. F. Schneider (stationed at Boskoop Research Station for Arboriculture).

Tomatoes, cucumbers etc.: Ir. J. M. Andeweg and Ir. K. Szteyn;

Herbs and tobacco: Ir. G. Elzenga, Ir. L. F. J. M. van der Ven (guest associate);

Leafy vegetables: Ir. J. A. Huyskes;

Pulses: Ir. E. Kooistra;

Cabbage crops: Ir. M. Nieuwhof;

Disease resistance tests: A. C. v. d. Giessen.

Tree fruits: Ir. A. S. de Bruyne;

Small fruits: Miss Ir. H. G. Kronenberg.

Floral Biology: Drs. J. P. Braak, Ir. Y. O. Kho and A. E. Zeilinga;

Physiology: Ir. L. Smeets;

Mathematical statistics and climate ecology: Ir, J. H. A. Ferguson;

Phytochemistry: Drs. J. W. de Bruyn;

Taxonomy of ornamental plants and street trees: Dr. B. K. Boom;

Taxonomy of fruit crops: Drs. E. T. Nannenga.

Visitors: G. Komen.

Publications: W Koopmans.

Matters concerning Plant Breeder's Right and Plant Introduction: W. E. G. de Bruin.

Secretary: R. Vos.

Accountant: J. W, van Eyndhoven. 